\title{
Ocena stopnia deficytu w zakresie podstawowych czynności dnia codziennego
}

\author{
Assessment of the deficit in basic activities of everyday life in relation \\ to persons covered by residential long-term car
}

MARIA MAGDALENA MACIEJEWSKA ${ }^{1}$

1 Zakład Opiekuńczo-Leczniczy, Szpital Lipno Sp. z o. o.

http://dx.doi.org/10.21784/IwP.2021.007

\section{Streszczenie}

Wstęp. Starzenie się organizmu jest dynamicznym i nieodwracalnym procesem naszego organizmu. Możliwość sprawowania samoopieki czyli wykonanie we własnym zakresie czynności takich jak poruszanie się, odżywianie, kontrolowanie potrzeb fizjologicznych i utrzymanie higieny osobistej należy utożsamić z niezależnością.

Cel. Celem pracy jest ocena stopnia deficytu w zakresie podstawowych czynności dnia codziennego wśród osób objętych opieką długoterminową stacjonarną.

Materiał i metody. W mojej pracy badawczej narzędziem jest analiza dokumentacji medycznej pacjentów w zakresie skali Barthel.

Wyniki. Analiza uzyskanych badań własnych pozwoliła na sformułowanie następujących wyników:

Płeć ma istotny wpływ na możliwość poruszania się badanych osób. Wiek ma znaczny wpływ na możliwość mycia, kąpieli całego ciała. Istnieje istotna zależność pomiędzy miejscem pobytu osób starszych a możliwością korzystania z toalety.

Wnioski. Płeć ma wpływ na możliwość poruszania się badanych osób. Wiek ma wpływ na możliwość mycia, kąpieli całego ciała. Istnieje zależność pomiędzy miejscem pobytu osób starszych a możliwością korzystania z toalety.

Słowa kluczowe: deficyt, problem, opieka, organizacja, senior 


\section{Summary}

Introduction. The aging of the organism is a dynamic and irreversible process of our organism. The possibility of exercising self-care, i.e. performing activities on one's own, such as walking, eating, controlling physiological needs and maintaining personal hygiene, should be equated with independence.

The aim. The aim of the study is to assess the deficit in basic everyday activities among people covered by long-term residential care.

Materials and methods. The tool in my research work is the analysis of patients' medical records in terms of the Barthel scale.

Results. The analysis of the obtained own research allowed for the formulation of the following results:

Gender has a significant impact on the mobility of the examined people. Age has a significant influence on the possibility of washing and bathing the whole body. There is a significant relationship between where older people live and the ability to use the toilet.

Conclusions. The level of stress, measured one year after the outbreak of the pandemic, does not indicate excessive stress, but the adaptation phase in a crisis situation. The effects of working under chronic stress may not be visible until the future. Further stress monitoring and providing nursing staff with psychological support is highly advisable.

Keywords: deficit, problem, care, organization, senior

\section{Wstęp}

Każdy człowiek niezależnie od pochodzenia czy też statusu społecznego zmierzy się w swoim życiu z procesem starzenia. To nie unikniony etap przez który musimy wszyscy przejść. Na całym świecie, również w Polsce wzrasta odsetek ludzi starzejących się, czyli powyżej 65. roku życia. Trendy demograficzne wskazują na ogromne spowolnienie rozwoju demograficznego, ale z dynamicznym postępem starzenia się, głównie w krajach dobrze rozwiniętych. Jest to oczywiście efekt pozytywnego zjawiska jakim jest wydłużanie przeciętnego trwania życia, ale także niestety spadku liczby urodzeń dzieci. Przedstawiają prognozy Eurostatu liczba ludności w wieku 65 lat i więcej w krajach Unii Euro- 
pejskiej (UE) ulegnie zwiększeniu z 97,7 mln w 2016 r. do 135,4 mln w 2035 r. [1].

Wraz z wydłużaniem się życia pojawiają się potrzeby zdrowotne seniora, które są konsekwencją postępującej niesprawności oraz polipatologii. Nieuniknionym staje się zatem zapewnienie długookresowych świadczeń diagnostycznych, terapeutycznych, a co najważniejsze profesjonalnych usług pielęgnacyjno-opiekuńczych, których nie są w stanie zapewnić opiekunowie rodzin. Deficyty sprawności funkcjonalnej dotyczą zarówno instrumentalnych jak i podstawowych czynności dnia codziennego z tendencją do ich pogłębiania się. Braki w niezależności przekładają się na samoocenę stanu zdrowia która w przypadku Polaków maleje wraz z zaawansowaniem wieku [1,2].

Wyróżniamy dwie niewątpliwie najważniejsze przyczyny starzenia demograficznego:

- długości życia, która nieustannie wzrasta, co jest skutkiem poprawy stanu zdrowia i jakości życia,

- utrzymująca się tendencja niskiego przyrostu naturalnego, co nie gwarantuje odtwarzania populacji na poziomie zastępowalności pokoleń, na przykład w państwach Unii Europejskiej w 2010 r. żyło 501, mln ludzi, a w poszczególnych grupach wiekowych liczebność przedstawiała się następująco:

- dzieci i młodzież w wieku 0-19 lat: 21,4\%

- osoby w wieku 20-64 lata: 61,3\%

- osoby w wieku 65 i więcej lat: 17,4\%

Singularyzacja starości oznacza samotne mieszkanie osób starszych. To jeden z kolejnych konsekwencji demograficznego starzenia się społeczeństwa. Natężenie urodzeń ma największy wpływ na dynamikę i poziom starzenia się. Od przeszło dwudziestu lat w Polsce zaobserwowano spadek liczby urodzeń, wynikiem tego jest zmniejszenie udziału najmłodszych grup wiekowych w populacji, adekwatny wzrost najstarszych roczników, a co za tym idzie zwiększenie liczby ludności w wieku średnim. Kolejną przyczyną starzenia się społeczeństwa tuż obok spadku liczby urodzeń jest wydłużenie się życia człowieka. Rozwój różnych 
nauk przyniósł postęp cywilizacyjny. Medycyna szczególnie przyczynia się do poprawy i wydłużenia życia. Wiedza na temat prowadzenia zdrowego stylu życia, wypoczynku, rekreacji, poprawy warunków, możliwości lepszego kształcenia zdecydowanie wpłynęły na poprawę kondycji zdrowotnej Polaków. Daje to również perspektywę przeżycia w starości większej ilości lat w wieku starszym. Zachodzące zmiany w procesie demograficznego starzenia się społeczeństwa powodują zapotrzebowanie na opiekę, świadczenia zdrowotne, pielęgnacyjno-opiekuńcze i socjalne w środowisku, w placówkach opieki długoterminowej, oraz opieki dziennej. W świadomości społecznej widnieje obraz emeryta który nie ma już przypisanych żadnych ról zawodowych i społecznych. Znaczący wpływ na zdrowie psychiczne jednostki ma niewątpliwie wycofanie się z życia społecznego. Negatywnie wpływa brak bodźców i wyzwań społecznych. Należy zauważyć że to na społeczeństwie i lokalnych instytucjach leży obowiązek zagospodarowania przestrzeni społecznej seniorów. Nie powinno być tak aby ich jedynym kontaktem społecznym był przyjazd listonosza czy wizyta u lekarza. Wielodyscyplinarne zespoły opieki długoterminowej oraz pielęgniarki pod nadzorem lekarza sprawują opiekę domową w systemie opieki zdrowotnej. Prawo wyraźnie określa sytuacje w których osobom starszym przysługują świadczenia z pomocy społecznej (Ustawa z dnia 12 marca 2004 r. o pomocy społecznej). Szczególną grupę odbiorców świadczeń w ochronie zdrowia stanowią pacjenci geriatryczni. Zazwyczaj to osoby z wielochorobowością u których z powodu różnych czynników istnieje ryzyko pogorszenia stanu zdrowia a tym samym pogłębienie deficytów samoopieki i samopielęgnacji [3].

Wielkie problemy geriatryczne zwane również wielkimi zespołami geriatrycznymi są to stopniowo narastające przewlekłe zaburzenia prowadzące do obniżenia sprawności i pogorszenia jakości życia osób w starszym wieku. Są wynikiem nakładania się zmian powstałych w wyniku przewlekłych zaburzeń w zakresie nietrzymania moczu i stolca (zaburzenia funkcji zwieraczy), upadków, zespołów otępiennych i depresji wieku podeszłego, oraz geriatrycznych zespołów jatrogennych. Nietrzymanie moczu (NTM) polega na bezwiednym, niezależnym od naszej woli wyciekaniu moczu 
przez cewkę w takiej częstości i ilości, że staje się dużym problemem społecznym i zdrowotnym, który znacząco wpływa pogorszenie jakości życia seniorów. Znacząco zwiększa ryzyko zakażeń układu moczowego, odleżyn oraz złamań i upadków wśród pacjentów w podeszłym wieku zmuszonych do oddawania moczu w nocy. Nietrzymanie stolca to utrata zależnej od woli kontroli nad wydalaniem stolca. W większości przypadków powodem nietrzymania stolca jest zaparcie i przenikanie płynnego stolca wokół zaklinowanych mas kałowych. Prawidłowe utrzymanie stolca w odbytnicy uzależnione jest od czucia w odbycie, odbytnicy, koordynacji wewnętrznego i zewnętrznego zwieracza odbytu. Upadki należą do częstych problemów wieku starczego. Częstość upadków wzrasta wraz z wiekiem. U seniorów 70-75 lat w ciągu roku wynoszą 47 razy, natomiast w wieku 80 i więcej 121 razy. Do grupy szczególnego ryzyka należą osoby przewlekle chore, niepełnosprawne i mało aktywne. Upadki niosą za sobą potencjalnie groźne następstwa takie jak ból, urazy, unieruchomienie które powodują że osoba starsza traci niezależność a to w znaczący sposób pogarsza jakość życia seniora poprzez ograniczenie jego sprawności.

Demencja stanowi jeden z najtrudniejszych problemów zdrowotnych i socjalnych ludzi starszych. Istnieje wyraźna różnica między otępieniem a depresją i zaburzeniami psychicznymi. Depresja natomiast jest zaburzeniem psychicznym, którego głównymi objawami są obniżenie nastroju, zahamowanie, niepokój [4].

\section{Cel}

Celem tego artykułu jest przedstawienie stopnia deficytu w zakresie podstawowych czynności dnia codziennego wśród osób objętych opieką długoterminową stacjonarną przebywających w Zakładzie Opiekuńczo-Leczniczym w Lipnie o profilu ogólnym, oraz dla psychicznie i nerwowo chorych.

\section{Materiał i metody}

W pracy wykorzystano metodę sondażu diagnostycznego. Technikami badawczymi, jakimi posłużono się dla potrzeb procesu badawcze- 
go były: ankietowanie oraz technika skali szacunkowej. Narzędzia użyte w pracy to: autorski kwestionariusz ankiety własnej oraz wystandaryzowane narzędzie badawcze jakim jest skala Barthel. Skala Barthel pozwala określić możliwości funkcjonowania w domu - zawiera rozszerzone aspekty skali Katza oraz dodatkowo ocenia poruszanie się po schodach i powierzchniach płaskich. Wskaźniki pozwalają określić stan czynnościowy chorego jako niesamodzielny ( 0 punktów), potrzebę pomocy (5 punktów) lub niezależny (10 punktów) w wykonywaniu danej aktywności. Skala ta pozwala ocenić sprawność z obszaru mycia, gdzie dokonuje się wyłącznie rozróżnienia na zależność od pomocy innych (0 punktów) lub samodzielność w wykonywaniu czynności (5 punktów) - oraz te związane z samodzielnością w poruszaniu się - wówczas skala Barthel pozwala dodatkowo określić również zakres koniecznej pomocy albo sprawność ruchu w odległości około $50 \mathrm{~m} \mathrm{w}$ pobliżu łóżka. Uzyskane wyniki niesamodzielności respondentów poddano analizie statystycznej Chi-kwadrat, opracowanej przez Karla Pearsona, pozwala na oszacowanie prawdopodobieństwa błędu hipotezy zerowej. Oblicza się przewidywany rozkład liczebności dwóch zmiennych, zwracając uwagę na empiryczne rozkłady ich liczebności.

Dzięki uzyskanym wynikom możemy odrzucić hipotezę zerową lub stwierdzić brak argumentów do jej odrzucenia. Wynik testu chi-kwadrat to różnica pomiędzy rozkładem łącznym zmiennych w próbie, a rozkładem wynikającym z założenia, iż zmienne te są niezależne od siebie. Otrzymane wyniki badań poddano analizie statystycznej testem $\chi^{2}$ dla prób niezależnych. Ryzyko błędu przyjęto na poziomie $5 \%$. Natomiast wartość prawdopodobieństwa $\mathrm{p}<0,05$ uznano za istotną statystycznie. Poziom istotności jest kolejnym kryterium niezbędnym do prawidłowego odczytu wyniku z tabeli statystycznej. W naukach medycznych najczęściej stosuje się wartość 0,05. Wynik testu chi-kwadrat porównuje się z wynikiem w tabeli.

\section{Wyniki}

Na podstawie przeprowadzonych badań na pacjentach w podeszłym wieku, przebywających w Zakładzie Opiekuńczo-Leczniczym 
w Lipnie została dokonana ocena sprawności funkcjonalnej opierająca się na skali Barthel. Wśród przebadanych 100 osób było 41\% mężczyzn zaś 59\% stanowiły kobiety. Badania wskazały, że wśród ankietowanych $25 \%$ stanowiły osoby w przedziale wiekowym między 60 a 70 lat, $30 \%$ stanowiły osoby w wieku 71-80 lat, 35\% ankietowanych stanowili pacjenci w wieku 81-90 lat, a 10\% badanych było powyżej 90 roku życia. Ankietowani w 34\% zamieszkiwali miasto, natomiast 66\% badanych pochodzi z obszarów wiejskich. Miejsce zamieszkania miało istotny wpływ na możliwości przemieszczania się pacjentów. Ponad $82 \%$ badanych mieszkających w mieście potrzebuje większej pomocy fizycznej, potrzebna jest jedna lub dwie osoby. Natomiast ponad $42 \%$ badanych

Tabela 1. Ocena zależności pomiędzy płcią ankietowanych a możliwością poruszania się.

\begin{tabular}{|c|c|c|c|c|c|c|c|c|c|}
\hline & \multicolumn{4}{|c|}{$\begin{array}{c}\text { Poruszanie się } \\
\text { (po powierzchniach płaskich) }\end{array}$} & \multirow[b]{2}{*}{$\frac{\Xi}{0}$} & \multirow[b]{2}{*}{$\chi^{2}$} & \multirow[b]{2}{*}{$\mathbf{p}$} \\
\hline & & & 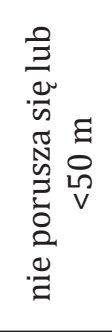 & 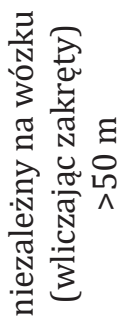 & 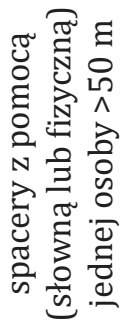 & 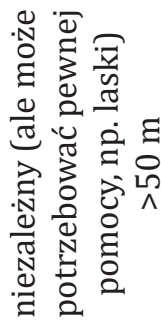 & & & \\
\hline \multirow{4}{*}{$\frac{\ddot{U}}{\pi}$} & \multirow{2}{*}{$\begin{array}{l}\frac{\pi}{0} \\
.0 \\
0 \\
0 \\
0\end{array}$} & $\mathbf{n}$ & 28 & 19 & 6 & 6 & 59 & \multirow{6}{*}{0,948} & \multirow{6}{*}{0,814} \\
\hline & & $\%$ & $47,5 \%$ & $32,2 \%$ & $10,2 \%$ & $10,2 \%$ & $100,0 \%$ & & \\
\hline & \multirow{2}{*}{ 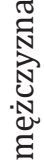 } & $\mathbf{n}$ & 21 & 14 & 2 & 4 & 41 & & \\
\hline & & $\%$ & $51,2 \%$ & $34,1 \%$ & $4,9 \%$ & $9,8 \%$ & $100,0 \%$ & & \\
\hline \multirow{2}{*}{\multicolumn{2}{|c|}{ Ogółem }} & $\mathbf{n}$ & 49 & 33 & 8 & 10 & 100 & & \\
\hline & & $\%$ & $49,0 \%$ & $33,0 \%$ & $8,0 \%$ & $10,0 \%$ & $100,0 \%$ & & \\
\hline
\end{tabular}

$\mathbf{n}$ - liczba obserwacji; p - poziom istotności statystycznej; $\chi^{2}$ - wynik testu chi kwadrat Persona 
mieszkających na wsi nie jest w stanie przemieszczać się, nie utrzymuje równowagi przy siedzeniu. Analiza statystyczna nie wykazała istotnej zależności pomiędzy płcią ankietowanych, a możliwością spożywania posiłków. Kobiety w 18\% nie są w stanie samodzielnie jeść a w 82\% potrzebują pomocy w krojeniu, smarowaniu i nalewaniu, w porównaniu do mężczyzn gdzie $25 \%$ nie jest w stanie samodzielnie jeść, a $75 \%$ wymaga pomocy w krojeniu, smarowaniu i nalewaniu.

Przeprowadzone badania wykazały, że nie ma istotnej zależności pomiędzy płcią ankietowanych a możliwością przemieszczania się. Kobiet, które nie były w stanie przemieszczać się, nie utrzymują równo-

Tabela 2. Ocena zależności pomiędzy wiekiem ankietowanych a możliwością mycia, kąpieli całego ciała.

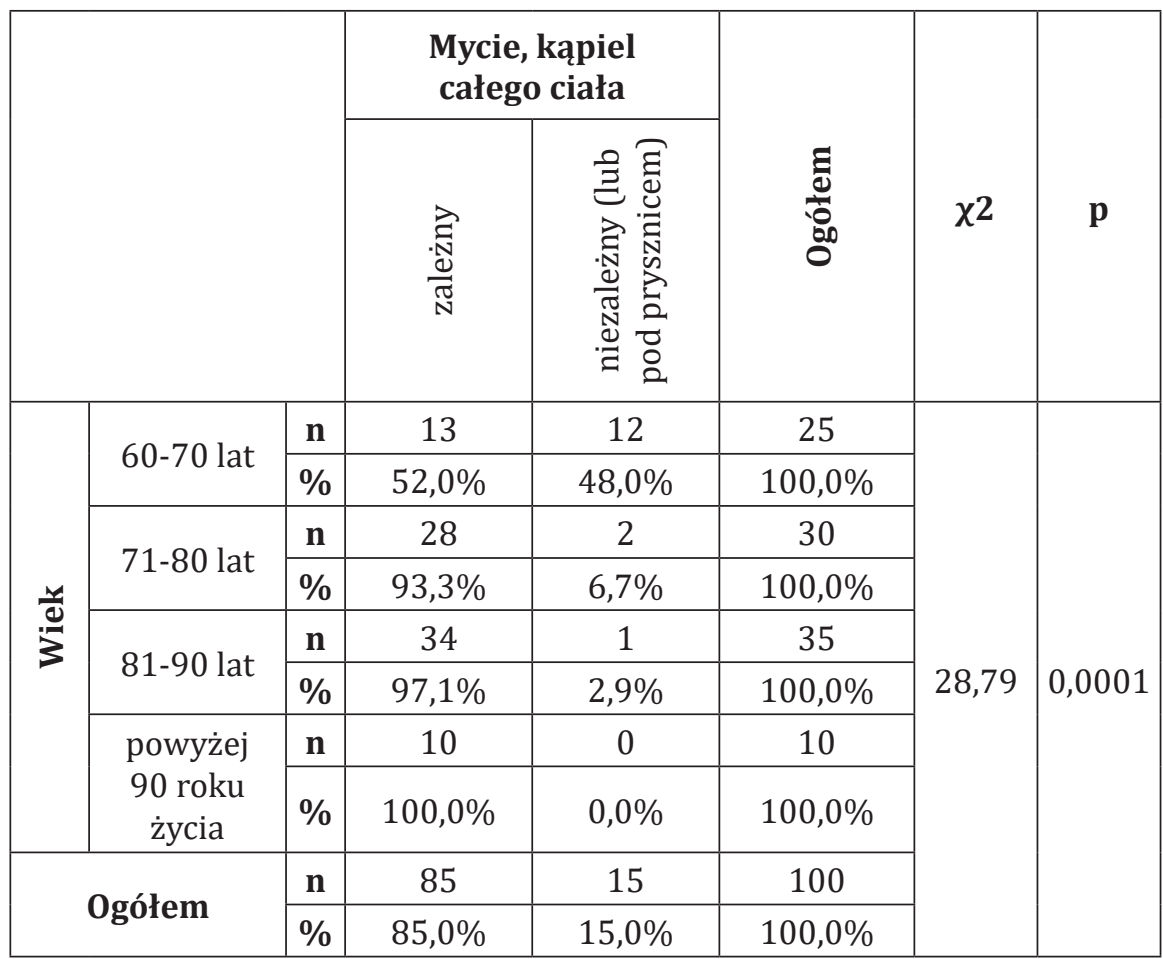

n - liczba obserwacji; p - poziom istotności statystycznej; $\chi^{2}$ - wynik testu chi kwadrat Persona 
wagi przy siedzeniu było 33,9\% w porównaniu do mężczyzn - 34,1\%. W śród mężczyzn potrzebujących większej pomocy fizycznej, gdzie potrzebna jest jedna lub dwie osoby było $63,4 \%$ w porównaniu do kobiet - 66,1\%. W śród kobiet którym potrzebna była mniejsza pomoc fizyczna lub słowna było 0,00\% w porównaniu do mężczyzn - 1\%.

Wśród badanych respondentów analiza statystyczna wykazała istotną zależność pomiędzy wiekiem ankietowanych a możliwością mycia, kąpieli całego ciała. 48\% badanych w wieku 60-70 lat jest niezależna. Natomiast ponad 97\% badanych w wieku 81-90 lat jest zależna od innych przy myciu, kąpieli całego ciała. $100 \%$ badanych po 90 roku życia jest całkowicie zależnych podczas mycia i kąpieli.

Tabela 3. Ocena zależność pomiędzy miejscem pobytu ankietowanych a możliwością korzystania z toalety.

\begin{tabular}{|c|c|c|c|c|c|c|c|c|}
\hline & \multicolumn{3}{|c|}{$\begin{array}{l}\text { Korzystanie z toalety } \\
\text { (WC) }\end{array}$} & \multirow[b]{2}{*}{ 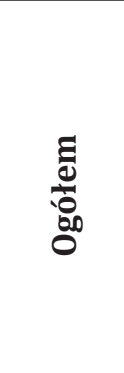 } & \multirow[b]{2}{*}{$\chi^{2}$} & \multirow[b]{2}{*}{$\mathbf{p}$} \\
\hline & & & $\begin{array}{l}\frac{\pi}{\pi} \\
\text { N } \\
\frac{0}{\pi} \\
N \\
\pi \\
0 \\
0 \\
0\end{array}$ & 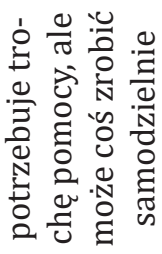 & 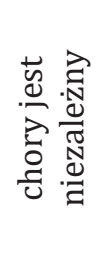 & & & \\
\hline \multirow{4}{*}{$\begin{array}{l}\frac{\pi}{\pi} \\
\frac{\pi}{\mathbb{N}} \\
0\end{array}$} & \multirow{2}{*}{$\begin{array}{c}\text { ZOL } \\
\text { o profilu } \\
\text { ogólnym }\end{array}$} & $\mathrm{n}$ & 64 & 6 & 0 & 70 & \multirow{6}{*}{40,71} & \\
\hline & & $\%$ & $91,4 \%$ & $8,6 \%$ & $0,0 \%$ & $100,0 \%$ & & \\
\hline & \multirow{2}{*}{$\begin{array}{c}\text { Zakład } \\
\text { Opiekuńczo- } \\
\text {-Leczniczy } \\
\text { dla } \\
\text { psychicznie } \\
\text { i nerwowo } \\
\text { chorych }\end{array}$} & $\mathbf{n}$ & 9 & 19 & 2 & 30 & & 0 \\
\hline & & $\%$ & $30,0 \%$ & $63,3 \%$ & $6,7 \%$ & $100,0 \%$ & & \\
\hline & \multirow{2}{*}{ Ogółem } & $\mathrm{n}$ & 73 & 25 & 2 & 100 & & \\
\hline & & $\%$ & $73,0 \%$ & $25,0 \%$ & $2,0 \%$ & $100,0 \%$ & & \\
\hline
\end{tabular}

$\mathbf{n}$ - liczba obserwacji; p - poziom istotności statystycznej; $\chi^{2}$ - wynik testu chi kwadrat Persona 
W wyniku przeprowadzonej analizy statystycznej wykazano istotną zależność pomiędzy miejscem pobytu ankietowanych a możliwością korzystania z toalety. Ponad 91\% badanych przebywających w Zakładzie Opiekuńczo-Leczniczym o profilu ogólnym są osobami zależnymi od innych podczas korzystania z toalety. Natomiast ponad $63 \%$ badanych przebywających Zakładzie Opiekuńczo-Leczniczym dla Psychicznie i Nerwowo chorych potrzebuje trochę pomocy, ale może coś zrobić samodzielnie.

Tabela 4. Ocena zależności pomiędzy miejscem pobytu ankietowanych a możliwością ubierania i rozbierania się.

\begin{tabular}{|c|c|c|c|c|c|c|c|}
\hline & \multicolumn{2}{|c|}{$\begin{array}{l}\text { Ubieranie się } \\
\text { i rozbieranie }\end{array}$} & \multirow[b]{2}{*}{$\frac{5}{0}$} & \multirow[b]{2}{*}{$\chi^{2}$} & \multirow[b]{2}{*}{ p } \\
\hline & & & 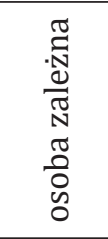 & 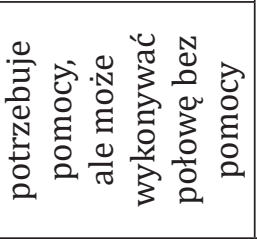 & & & \\
\hline \multirow{4}{*}{$\begin{array}{l}\frac{\pi}{\pi} \\
\frac{\pi}{0} \\
\end{array}$} & & $\mathbf{n}$ & 65 & 5 & 70 & \multirow{6}{*}{33,12} & \multirow{6}{*}{0,0001} \\
\hline & ogólnym & $\%$ & $92,9 \%$ & $7,1 \%$ & $100,0 \%$ & & \\
\hline & $\begin{array}{c}\text { Zakład } \\
\text { Opiekuńczo- } \\
\text {-Leczniczy }\end{array}$ & $\mathbf{n}$ & 12 & 18 & 30 & & \\
\hline & $\begin{array}{c}\text { psychicznie } \\
\text { i nerwowo } \\
\text { chorych }\end{array}$ & $\%$ & $40,0 \%$ & $60,0 \%$ & $100,0 \%$ & & \\
\hline \multirow{2}{*}{\multicolumn{2}{|c|}{ Ogółem }} & $\mathbf{n}$ & 77 & 23 & 100 & & \\
\hline & & $\%$ & $77,0 \%$ & $23,0 \%$ & $100,0 \%$ & & \\
\hline
\end{tabular}

$\mathbf{n}$ - liczba obserwacji; $\mathbf{p}$ - poziom istotności statystycznej; $\chi^{2}$ - wynik testu chi kwadrat Persona

Analiza statystyczna wykazała istotną zależność pomiędzy miejscem pobytu ankietowanych a możliwością poruszania się. Ponad $65 \%$ badanych przebywających w Zakładzie Opiekuńczo-Leczniczym o profilu ogólnym nie porusza się lub mniej niż $50 \mathrm{~m}$. Natomiast $53 \%$ bada- 
nych przebywających Zakładzie Opiekuńczo-Leczniczym dla Psychicznie i Nerwowo chorych są niezależni na wózku.

Tabela 5. Ocena zależności pomiędzy liczbą występujących schorzeń $\mathrm{u}$ ankietowanych a ich wynikiem kwalifikacji.

\begin{tabular}{|c|c|c|c|c|c|c|c|}
\hline & & & \multicolumn{2}{|c|}{ Wynik kwalifikacji } & \multirow[b]{2}{*}{$\frac{\Xi}{0}$} & \multirow[b]{2}{*}{$\chi^{2}$} & \multirow[b]{2}{*}{$\mathbf{p}$} \\
\hline & & & 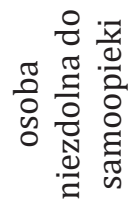 & 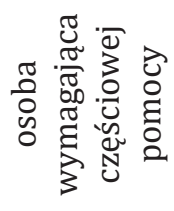 & & & \\
\hline \multirow{3}{*}{ 胥 } & \multirow{2}{*}{1} & $\mathbf{n}$ & 12 & 11 & 23 & \multirow{14}{*}{33,12} & \multirow{14}{*}{0,0001} \\
\hline & & $\%$ & $52,2 \%$ & $47,8 \%$ & $100,0 \%$ & & \\
\hline & \multirow{2}{*}{2} & $\mathbf{n}$ & 12 & 9 & 21 & & \\
\hline \multirow{9}{*}{ 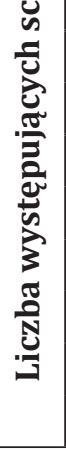 } & & $\%$ & $57,1 \%$ & $42,9 \%$ & $100,0 \%$ & & \\
\hline & \multirow{2}{*}{3} & $\mathbf{n}$ & 25 & 9 & 34 & & \\
\hline & & $\%$ & $73,5 \%$ & $26,5 \%$ & $100,0 \%$ & & \\
\hline & \multirow{2}{*}{4} & $\mathbf{n}$ & 8 & 1 & 9 & & \\
\hline & & $\%$ & $88,9 \%$ & $11,1 \%$ & $100,0 \%$ & & \\
\hline & \multirow{2}{*}{5} & $\mathbf{n}$ & 11 & 0 & 11 & & \\
\hline & & $\%$ & $100,0 \%$ & $0,0 \%$ & $100,0 \%$ & & \\
\hline & \multirow{2}{*}{6} & $\mathbf{n}$ & 2 & 0 & 2 & & \\
\hline & & $\%$ & $100,0 \%$ & $0,0 \%$ & $100,0 \%$ & & \\
\hline \multirow{2}{*}{\multicolumn{2}{|c|}{ Ogółem }} & $\mathbf{n}$ & 70 & 30 & 100 & & \\
\hline & & $\%$ & $70,0 \%$ & $30,0 \%$ & $100,0 \%$ & & \\
\hline
\end{tabular}

$\mathbf{n}$ - liczba obserwacji; p - poziom istotności statystycznej; $\chi^{2}$ - wynik testu chi kwadrat Persona

Badania statystyczne nie wykazały istotnej zależności pomiędzy liczbą występujących schorzeń u ankietowanych a możliwością utrzymania higieny osobistej. Pacjentów potrzebujących pomocy przy czynnościach osobistych z jedną chorobą było 91,3\%, natomiast podopiecznych posiadających aż 6 jednostek chorobowych było 100\%. 
Analiza statystyczna nie wykazała istotnej zależności pomiędzy liczbą występujących schorzeń u ankietowanych a możliwością kontrolowania stolca/zwieracza odbytu. Chorych nie panujących nad oddawaniem stolca (lub potrzebujących lewatyw) posiadających 1 chorobę było $73,9 \%$ w porównaniu do podopiecznych posiadających 3 jednostki chorobowe - 82,4\%.

Po przeprowadzeniu analizy uzyskanych wyników badań oceny sprawności pacjentów w skali Barthel stwierdzono, że 30\% badanych wymaga częściowej pomocy. Natomiast $70 \%$ respondentów jest niezdolnych do samoopieki.

Analiza uzyskanych wyników wykazała istotną zależność pomiędzy miejscem pobytu ankietowanych a wynikiem kwalifikacji. Ponad 88\% badanych przebywających w Zakładzie Opiekuńczo-Leczniczym o profilu ogólnym są osobami niezdolnymi do samoopieki. Natomiast ponad 73\% badanych przebywających Zakładzie Opiekuńczo Leczniczym dla Psychicznie i Nerwowo chorych są osobami wymagającymi częściowej pomocy.

\section{Dyskusja}

Głównymi przyczynami starzenia demograficznego są, długości życia, która nieustannie wzrasta, co jest skutkiem poprawy stanu zdrowia i jakości życia, oraz utrzymująca się tendencja niskiego przyrostu naturalnego, co nie gwarantuje odtwarzania populacji na poziomie zastępowalności pokoleń, na przykład w państwach Unii Europejskiej w 2010 r. żyło 501, mln ludzi, a w poszczególnych grupach wiekowych liczebność przedstawiała się następująco, dzieci i młodzież w wieku 0-19 lat: 21,4\%, osoby w wieku 20-64 lata: 61,3\%, osoby w wieku 65 i więcej lat: 17,4\% [4, 5].

Kobiety coraz częściej decydują się na urodzenie pierwszego dziecka w późnym wieku. Powodów takiej decyzji jest kilka, mianowicie większa aktywność zawodowa, oraz dłuższy okres nauki. Spadek zawieranych małżeństw również pogłębia zjawisko spadku urodzeń [4].

Od ostatniej dekady ubiegłego wieku, w Polsce systematycznie opisuje się spadek liczby zgonów i wydłużenie życia. Efektem tej sytuacji jest coraz lepszy stan zdrowia seniorów czyli malejąca liczba zgonów z powodu niektórych chorób nowotworowych ale szczególnie z powo- 
du chorób układu krążenia. Nieustannie utrzymuje się wyższa umieralność mieszkańców obszarów wiejskich niż miast [1].

Zachodzące zmiany w procesie demograficznego starzenia się społeczeństwa powodują zapotrzebowanie na opiekę, świadczenia zdrowotne, pielęgnacyjno-opiekuńcze i socjalne w środowisku, w placówkach opieki długoterminowej, oraz opieki dziennej.

Dynamiczne przemiany ekonomiczno-demograficzne sprawiły że osoby starsze stały się głównymi odbiorcami świadczeń zdrowotnych. Seniorzy są głównym źródłem kosztów społecznych i odbiorcą świadczeń zdrowotnych. W Polsce istnieją różnorodne formy opieki nad seniorami. Istnieje instytucjonalna i pozainstytucjonalna opieka geriatryczna.

Zakład Opiekuńczo-Leczniczy (ZOL) to forma stacjonarnej opieki długoterminowej. Podstawowym celem ZOL-u jest udzielenie całodobowych świadczeń zdrowotnych, objęcie leczeniem, oraz pielęgnacją przez całą dobę i rehabilitację osób u których zakończono proces diagnozowania, leczenia operacyjnego. Do Zakładu Opiekuńczo-Leczniczego może zostać przyjęta osoba, która w ocenie stanu samoobsługi pacjenta otrzymała maksymalnie 6 punktów (na podstawie załącznika karta samoobsługi wg ADL, lub 0 do 40 pkt. wg skali Barthel).

Z przeprowadzonych badań wynika, że 30\% badanych wymaga częściowej pomocy. Natomiast 70\% respondentów jest niezdolnych do samoopieki. Skalę Barthel stosuje się w celu oceny stanu pacjenta. W Polsce, skala Barthel używana jest jako narzędzie do określania dostępności do opieki długoterminowej (stacjonarnej i domowej). Osoby, których wynik nie przekracza 40 punktów mogą liczyć na zakwalifikowanie do opieki długoterminowej.

\section{Wnioski}

1. Płeć ma wpływ na możliwość poruszania się badanych osób.

2. Wiek ma wpływ na możliwość mycia, kąpieli całego ciała.

3. Istnieje zależność pomiędzy miejscem pobytu osób starszych a możliwością korzystania z toalety. 
4. Miejsce pobytu ankietowanych ma wpływ na możliwość ubierania i rozbierania się.

5. Nie ma istotnej zależności pomiędzy liczbą występujących schorzeń u ankietowanych, a ich wynikiem kwalifikacji do Zakładu Opiekuńczo-Leczniczego.

\section{Zalecenia dla praktyki pielęgniarskiej}

Do pielęgniarki należy wiele zadań związanych z opieką nad chorym przebywającym w Zakładzie Opiekuńczo-Leczniczym. Największymi problemami z jakimi boryka się chory to przede wszystkim stopniowo narastające przewlekłe zaburzenia prowadzące do obniżenia sprawności i pogorszenia jakości życia w starszym wieku. Nietrzymanie moczu i stolca (zaburzenia funkcji zwieraczy), upadki, zespoły otępienne i depresje wieku podeszłego, a także geriatryczny zespół jatrogenny to główne czynniki wpływające na sprawność funkcjonalną chorego, którym pielęgniarka musi podołać w swojej pracy każdego dnia. Aby zapewnić jak najwyższą jakość opieki, konieczne jest posiadanie wiedzy i umiejętności na temat pacjenta chorego przewlekle somatycznie jak i z zaburzeniami psychicznymi w ujęciu interdyscyplinarnym.

\section{Bibliografia/ Bibliography:}

1. Wieczorkowska Tobis K., Talarska D. Geriatria i pielęgniarstwo geriatryczne. Wyd. PZWL, Warszawa 2015:145-167.

2. Wieczorkowska-Tobis K., Kostka T., Borowicz A.M. Fizjoterapia w geriatrii. Praca zbiorowa. Wyd. PZWL, Warszawa 2010:35-55.

3. GUS., Sytuacja demograficzna osób starszych i konsekwencje starzenia się ludności Polski w świetle prognozy na lata 2014-2050. Warszawa 2014:7-8

4. Kędziora-Kornatowska K., Muszalik M., Skolmowska E. Pielęgniarstwo w opiece długoterminowej. Wyd. PZWL. Warszawa 2010.

5. Górna K., Jaracz K., Rybakowski J. Pielęgniarstwo psychiatryczne. Podręcznik dla studentów medycznych. Wyd. Lek. PZWL, Warszawa 2012. 